Phonetica 1993;50:141-143

\title{
Contents, Vol. 50, No. 3, 1993
}

\section{Contents}

Barry, W.J.; Diehl, R.; Kohler, K.J. Editorial Note 145

Liberman, M.; Schultz, J.M.; Hong, S.; Okeke, V. The Phonetic Interpretation of Tone in Igbo 147

Caspers, J.; van Heuven, V.J. Effects of Time Pressure on the Phonetic Realization of the Dutch Accent-Lending Pitch Rise and Fall 161

Shriberg, E.E.; Lickley, R.J. Intonation of Clause-Internal Filled Pauses 172

Sluijter, A.M.C.; Terken, J.M.B. Beyond Sentence Prosody: Paragraph Intonation in Dutch 180

Swerts, M.; Geluykens, R. The Prosody of Information Units in Spontaneous Monologue 189

Nakajima, S.; Allen, J.F. $\quad$ A Study on Prosody and Discourse Structure in 197

Cooperative Dialogues

Publications Received for Review

211 